\title{
PENGARUH LAMA PEMBAKARAN DAN JENIS BAHAN BAKAR TERHADAP KUALITAS SENSORIS DAN KADAR BENZO(A)PIREN SATE DAGING KAMBING
}

\author{
THE EFFECT OF GRILLING TIME AND FUEL TYPE ON THE SENSORY QUALITY AND \\ BENZO(A)PYRENE LEVELS OF GOAT MEAT SATAY
}

\author{
Bayu Etti Tri Adiyastiti*, Edi Suryanto, dan Rusman \\ Fakultas Peternakan, Universitas Gadjah Mada, Jl. Fauna No. 3, Bulaksumur, Yogyakarta, 55281
}

\section{INTISARI}

Penelitian ini bertujuan untuk mengetahui pengaruh lama pembakaran dan jenis bahan bakar terhadap kualitas sensoris dan kadar benzo(a)piren sate daging kambing. Persiapan awal daging dipisahkan dari jaringan lemak kemudian direndam dalam bumbu dan dibakar sesuai dengan perlakuan. Perlakuan lama pembakaran adalah 3, 5 dan 7 menit dengan masing-masing dibakar menggunakan arang dan gas. Parameter yang diamati adalah kualitas sensoris dan kadar benzo(a)piren. Data kualitas sensoris dianalisis dengan analisis non parametrik metode Kruskal-Wallis dan kadar benzo(a)piren secara deskriptif. Hasil analisis statistik menunjukkan bahwa lama pembakaran berpengaruh nyata $(\mathrm{P}<0,05)$ terhadap warna, rasa, juiciness dan daya terima, akan tetapi berpengaruh tidak nyata terhadap bau (aroma) dan tekstur. Jenis bahan bakar berpengaruh tidak nyata terhadap kualitas sensoris. Kadar benzo(a)piren sate daging kambing dengan lama pembakaran 3, 5, dan 7 menit menggunakan arang berturut-turut adalah 2,55 ppb; 4,16 ppb dan 5,02 ppb, sedangkan menggunakan gas adalah $0,68 \mathrm{ppb} ; 2,71 \mathrm{ppb}$ dan 1,65 ppb. Kesimpulan dari penelitian ini adalah lama pembakaran menghasilkan perubahan warna, rasa, juiciness, daya terima dan kadar benzo(a)piren sate daging kambing. Jenis bahan bakar arang menghasilkan kadar benzo(a)piren lebih tinggi pada sate daging kambing.

(Kata kunci: Sate daging kambing, Benzo(a)piren, Kualitas sensoris)

\begin{abstract}
This study was conducted to determine the effect of grilling time and fuel type on the sensory quality and benzo(a)pyrene levels in goat meat satay. As the first preparation, the meat was trimmed from fat tissue, then marinated with herbs and grilled according the treatments. The grilling time were 3, 5 and 7 minutes by charcoal and gas. Parameters measured were sensory qualities and benzo(a)pyrene level. The data were analyzed by Kruskal-Wallis nonparametric method for sensory quality and benzo(a)pyrene level would be explained descriptively. Statistical analysis results showed that the grilling time were significantly $(P<0.05)$ influenced the meat's color, flavor, juiciness and acceptance, but it did not significantly affected meat's smell (aroma) and texture. The type of fuel did not significantly determine the sensory quality. The levels of benzo(a)pyrene goat meat satay of charcoal fuel with 3, 5 and 7 minutes grilling time in sequence were $2.55 \mathrm{ppb}$; $4.16 \mathrm{ppb}$ and $5.02 \mathrm{ppb}$, while using gas were $0.68 \mathrm{ppb}$; $2.71 \mathrm{ppb}$ and $1.65 \mathrm{ppb}$ respectively. The conclusions of this study were grilling time affected changes the color, flavor, juiciness, acceptance and levels of benzo(a)pyrene of goat meat satay. Charcoal fuel produced a higher level of benzo(a)pyrene in goat meat satay.
\end{abstract}

(Keywords: Goat meat satay, Benzo(a)pyrene, Sensory quality)

\section{Pendahuluan}

Produk olahan daging kambing yang dikenal masyarakat adalah sate dan tongseng. Berdasarkan Direktorat Jenderal Peternakan (2011), jumlah populasi ternak kambing mengalami peningkatan tiap tahunnya. Jumlah populasi pada tahun 2010 yaitu 16.620.000 ekor dan pada tahun 2011 yaitu 17.843.000 ekor. Sate diproses dengan cara dibakar menggunakan arang, batok kelapa atau menggunakan pemanggang dengan bahan bakar gas. Pembakaran dilakukan secara manual menggunakan

\footnotetext{
* Korespondensi (corresponding author):

Telp. +62 85702226668

E-mail: bayu_etti@yahoo.com
}

kipas tangan dengan tingkat kematangan berdasarkan perasaan atau pengalaman membakar sate. Sate dibakar dengan suhu yang tinggi, sehingga dapat mempengaruhi sifat fisik dan kimia daging sate tersebut.

Faktor penting dalam pemasakan adalah lama pemasakan karena dapat mempengaruhi kualitas daging. Perbedaan lama pembakaran akan memberikan tekstur dan rasa yang berbeda pada sate daging kambing sehingga akan mempengaruhi penilaian oleh konsumen secara subyektif.

Sate diduga memiliki cemaran kimia yaitu zat karsinogenik karena proses pembakaran pada suhu 
tinggi. Polisiklik aromatik hidrokarbon $(\mathrm{PAH})$ merupakan kelompok senyawa yang terbentuk akibat pembakaran yang tidak sempurna dari zat-zat anorganik (arang, minyak, dan gas) serta zat organik. Dalam daging yang dipanggang, PAH terbentuk saat lemak daging menetes di atas arang, kemudian menyatu dalam asap dan menempel pada daging. Komponen PAH terutama benzo(a)piren merupakan jenis $\mathrm{PAH}$ yang memiliki tingkat karsinogenik tinggi dan telah umum digunakan sebagai indikator adanya kelompok PAH (Benford et al., 2010).

Jenis bahan bakar yang digunakan diduga juga dapat mempengaruhi kadar $\mathrm{BaP}$ dalam daging bakar. Pembakaran sate dengan arang lebih sering digunakan dan disukai oleh masyarakat. Arang merupakan hasil pembakaran tidak sempurna yang di dalamnya terdapat kandungan PAH. Bahan bakar gas telah digunakan untuk pemasakan olahan daging seperti barbecue. Menurut Widiarto et al. (2011) gas LPG komponen utamanya adalah gas propana $\left(\mathrm{C}_{3} \mathrm{H}_{8}\right)$ dan butana $\left(\mathrm{C}_{4} \mathrm{H}_{10}\right)$ kurang lebih 99\% dan selebihnya adalah zat pembau. Pembakaran dengan bahan bakar gas diduga lebih rendah kadar cemarannya di dalam daging bakar, selain itu lebih praktis penggunaannya dibandingkan dengan jenis bahan bakar arang.

Penelitian ini dilakukan untuk mengetahui kualitas sensoris dan kadar benzo(a)piren sate daging kambing yang diolah dengan lama pembakaran dan jenis bahan bakar yang berbeda, sehingga dapat memberikan informasi tentang keamanan dalam mengkonsumsi sate daging kambing.

\section{Materi dan Metode}

\section{Materi}

Alat yang digunakan adalah tusuk sate bambu, tungku, kompor gas, termometer digital, timbangan analitik, pisau, talenan, penggaris, kamera, alat tulis, baskom, piring, erlenmeyer, gelas ukur, beker glass, labu ukur, corong pisah, botol kaca, rotary evaporator, gloves, masker, pipet, corong, cartridge sep-pak florisil, spuit $10 \mathrm{ml}$, vortex, pengaduk, waterbath, gas Chromatography merk Shimadzu tipe GC-2010.
Bahan yang digunakan adalah daging kambing Kacang pre rigor umur 9-10 bulan (belum poel), arang kayu kelengkeng, bumbu-bumbu, $\mathrm{KOH}$ $50 \%$, dichloromethane $\left(\mathrm{CH}_{2} \mathrm{Cl}_{2}\right)$, methanol, aquades, $\mathrm{N}_{2}$, kertas saring, plastik, karet gelang, dan tissue.

\section{Metode}

Proses awal penelitian dilakukan dengan survei lapangan ke-10 tempat penjual sate yang terdapat di daerah sekitar kota Yogyakarta. Pengambilan data dilakukan dengan wawancara langsung terhadap pedagang sate untuk mendapatkan data lama pembakaran dan suhu internal sate daging kambing dengan kriteria setengah matang, matang, dan matang sekali. Selain itu, dilakukan pengukuran ketebalan daging, jarak bara api dan informasi lain yang dibutuhkan. Data yang didapatkan digunakan sebagai pedoman untuk penelitian selanjutnya.

Pembuatan sate daging kambing. Persiapan awal disiapkan bumbu yang dihaluskan. Bumbu terdiri dari bawang putih $35,70 \mathrm{~g}$ (7 siung), ketumbar $4 \mathrm{~g}$, merica $3 \mathrm{~g}$, kencur $3 \mathrm{~g}$, asam jawa 13 g, garam 4 g, dan gula jawa 150 g. Daging kambing yang telah dihilangkan lemaknya ditimbang $1 \mathrm{~kg}$, kemudian dipotong balok dengan ukuran $3 \times 2 \times 1,5 \mathrm{~cm}$, direndam dalam bumbu yang telah dihaluskan selama 15 menit. Daging ditusuk dengan tusuk sate dari bambu, terdiri dari 4 potong daging. Air rendaman diukur sebanyak $60 \mathrm{ml}$ dan diberi tambahan kecap $50 \mathrm{ml}$ untuk bahan celupan ketika pembakaran. Pembakaran sate dilakukan dengan perlakuan lama pembakaran 3, 5, dan 7 menit dan 2 jenis bahan bakar yaitu arang dan gas. Rerata suhu internal dan lama pembakaran disajikan pada Tabel 1.

Analisis kualitas sensoris. Kualitas sensoris berdasarkan 15 panelis, meliputi warna, bau, rasa, tekstur, juiciness dan daya terima. Kuesioner menggunakan skala hedonik 5 poin yang diadaptasi dari Watts et al. (1989) dan Suryanto (2000) cit Tiven et al. (2007), untuk bau, rasa, juiciness, dan daya terima dengan skala $1=$ sangat suka, $2=$ suka, $3=$ agak suka, $4=$ tidak suka dan $5=$ sangat tidak suka. Skala untuk warna yaitu $1=$ coklat, $2=$ sangat coklat, $3=$ agak hitam, $4=$ hitam dan $5=$ sangat

Tabel 1. Rerata suhu internal dan lama pembakaran sate daging kambing (the average of internal temperature and grilling time goat meat satay)

\begin{tabular}{lccc}
\hline \hline \multicolumn{1}{c}{ Variabel (variable) } & $\begin{array}{c}\text { Setengah matang } \\
(\text { medium })\end{array}$ & $\begin{array}{c}\text { Matang } \\
\text { (welldone) }\end{array}$ & $\begin{array}{c}\text { Matang sekali } \\
\text { (very welldone) }\end{array}$ \\
\hline Lama pembakaran (menit) ( grilling time $($ minute) $)$ & 3 & 5 & 7 \\
Suhu internal $\left({ }^{\circ} \mathrm{C}\right)$ (internal temperature $\left({ }^{\circ} \mathrm{C}\right)$ ) & $62,07 \pm 1,23$ & $73,30 \pm 2,80$ & $85,17 \pm 4,86$ \\
\hline
\end{tabular}


hitam. Tekstur dengan skala 1 = sangat halus, $2=$ halus, $3=$ agak kasar, $4=$ kasar dan $5=$ sangat kasar.

Analisis kadar benzo(a)piren. Analisis kadar benzo(a)piren diadaptasi dari Chen dan Chen (2004) yang telah dimodifikasi. Sampel sebanyak $25 \mathrm{~g}$ dihaluskan, kemudian dicampur dengan $15 \mathrm{ml}$ $\mathrm{KOH} 50 \%$. Setelah itu dimasukkan ke dalam waterbath $70^{\circ} \mathrm{C}$ selama 30 menit dengan sesekali digoyangkan. Ekstraksi dilakukan dua kali, ekstraksi pertama dengan $15 \mathrm{ml} \mathrm{CH}_{2} \mathrm{Cl}_{2}$. Ekstraksi kedua dengan $10 \mathrm{ml} \mathrm{CH}_{2} \mathrm{Cl}_{2}$ dan ditampung. Ekstrak yang didapat diuapkan sampai $5 \mathrm{ml}$ dengan rotary evaporator. Cartridge Sep-Pak florisil diaktifkan dengan methanol. Konsentrat yang didapatkan dimasukkan ke dalam catridge Sep-Pak florisil. Alikuot methanol $10 \mathrm{ml}$ digunakan untuk melarutkan bahan kimia dan hasilnya dikumpulkan, kemudian dievaporasi sampai kering dengan $\mathrm{N}_{2}$, diencerkan dengan $1 \mathrm{ml} \mathrm{CH}_{2} \mathrm{Cl}_{2}$ dan diinjeksikan ke gas Chromatography.

Gas Chromatography yang digunakan adalah Shimadzu tipe GC-2010, jenis kolom adalah CPSil8-CB dengan panjang 30 meter, diameter dalam $0,25 \mathrm{~mm}$ dengan tebal film $0,25 \mu \mathrm{m}$. Suhu kolom $270^{\circ} \mathrm{C}$ selama 3 menit. Gas pembawa adalah $\mathrm{He}$, $100 \mathrm{kPa}$. Detektor FID dengan suhu $320^{\circ} \mathrm{C}$, injector $1 \mu 1$ suhu $320^{\circ} \mathrm{C}$.

Penghitungan nilai kadar benzo(a)piren dengan penghitungan area puncak dari larutan standar didapatkan regresi linear $\mathrm{Y}=\mathrm{BX}+\mathrm{A}$, didapatkan nilai $\mathrm{X}$, kemudian dihitung dengan rumus:

$$
\text { Kadar benzo(a)piren }=\frac{\mathrm{X} \text { x volume akhir }}{\text { berat sampel }}
$$

\section{Analisis data}

Kualitas sensoris dianalisis dengan analisis non parametrik metode Kruskal-Wallis dan kadar benzo(a)piren secara deskriptif dan apabila terdapat perbedaan dilakukan uji lanjut Duncan's new Multiple Range Test (Steel dan Torrie, 1993).

\section{Hasil dan Pembahasan}

\section{Pengolahan sate daging kambing di lapangan}

Hasil pra penelitian interview dengan pedagang sate daging kambing yaitu suhu internal, lama pembakaran, ketebalan daging dan jarak bara api dengan sate yang dibakar disajikan pada Tabel 2.

Hasil ini sesuai dengan hasil penelitian yang dilakukan oleh Taufik (2006), ketebalan rerata daging sate adalah $1,59 \mathrm{~cm}$, jarak bara adalah $4,23 \mathrm{~cm}$. Rerata tingkat panas pembakaran sate setengah matang adalah $61,89^{\circ} \mathrm{C}$ dengan waktu rerata adalah 2 menit 43 detik dan rerata tingkat pemanas sate matang adalah $77,31^{\circ} \mathrm{C}$ dengan waktu rerata lama pembakaran 5 menit (300,4 detik).

Menurut pedagang sate indikasi matang yaitu telah terjadinya perubahan warna menjadi lebih gelap atau terbentuk warna coklat gelap kehitaman di permukaan daging. Sate setengah matang berwarna agak coklat dan bagian dalamnya masih berwarna merah. Sate matang tekstur tidak terlalu kering, bagian luar dan dalam daging berwarna coklat. Sate matang sekali berwarna coklat kehitaman dengan tekstur kering.

\section{Kualitas sensoris sate daging kambing}

Kualitas sensoris merupakan kualitas daging berdasarkan konsumen yang bersifat subjektif dan parameter yang penting secara komersial. Hasil kualitas sensoris sate daging kambing dengan lama pembakaran dan bahan bakar yang berbeda disajikan pada Tabel 3.

\section{Warna sate daging kambing}

Hasil analisis menunjukkan bahwa lama pembakaran berpengaruh nyata terhadap warna sate daging kambing. Warna daging pada pembakaran 3 menit di dalam skala 1-2 masih menunjukkan warna coklat. Pembakaran 5 menit menunjukkan warna coklat dan lama pembakaran 7 menit menunjukkan warna agak hitam. Moeljanto (1998) menyatakan bahwa warna dihasilkan karena adanya reaksi kimia antara fenol dan $\mathrm{O}_{2}$ serta antara protein dan karbonil pada bahan yang dipanggang. Dengan demikian semakin tinggi kadar fenol dan karbonil dalam asap, maka warna daging akan semakin kuning keemasan atau kecoklatan.

Warna coklat pada sate daging kambing diduga karena terjadinya reaksi maillard. Reaksi maillard adalah reaksi antara protein dengan gula pereduksi (Muchtadi et al., 1993). Kusnandar (2010) menyatakan bahwa reaksi maillard menghasilkan pigmen melanoidin yang bertanggungjawab pada pembentukan warna coklat dan reaksi karamelisasi menghasilkan warna coklat melalui reaksi kimia yang terjadi pada gula sederhana karena adanya proses pemanasan.

Warna adalah refleksi cahaya pada permukaan bahan yang ditangkap oleh indera penglihatan dan ditransmisi oleh sistem syaraf. Warna mempengaruhi penerimaan suatu bahan pangan, karena umumnya penerimaan bahan yang pertama kali dilihat adalah warna. Warna yang menarik akan meningkatkan penerimaan produk. Warna dapat mengalami perubahan saat pemasakan. Hal ini dapat disebabkan oleh hilangnya sebagian pigmen akibat pelepasan cairan sel pada saat pemasakan atau pengolahan, intensitas warna semakin menurun (Beriain et al., 2000). 
Tabel 2. Suhu internal, lama pembakaran, ketebalan daging dan jarak bara sate daging kambing penelitian lapangan (the internal temperature, grilling time, thickness and ember distance of goat meat satay field research)

\begin{tabular}{lccc}
\hline \hline \multicolumn{1}{c}{ Variabel (variable) } & $\begin{array}{c}\text { Setengah matang } \\
(\text { medium })\end{array}$ & $\begin{array}{c}\text { Matang } \\
(\text { welldone })\end{array}$ & $\begin{array}{c}\text { Matang sekali } \\
\text { (very welldone })\end{array}$ \\
\hline $\begin{array}{l}\text { Lama pembakaran (menit) (grilling duration } \\
(\text { minute) })\end{array}$ & $2.95 \pm 0.35$ & $5.35 \pm 1.01$ & $7.35 \pm 1.91$ \\
Suhu internal $\left({ }^{\circ} \mathrm{C}\right)\left(\right.$ internal temperature $\left({ }^{\circ} \mathrm{C}\right)$ ) & $53,88 \pm 5,07$ & $70,82 \pm 3,97$ & $80,70 \pm 2,62$ \\
Ketebalan $(\mathrm{cm})$ (thickness $(\mathrm{cm}))$ & $\pm 1,5$ & $\pm 1,5$ & $\pm 1,5$ \\
Jarak bara $(\mathrm{cm})($ ember distance $(\mathrm{cm}))$ & \pm 4 & \pm 4 & \pm 4 \\
\hline
\end{tabular}

Tabel 3. Rerata skor sensoris sate daging kambing dengan lama pembakaran dan jenis bahan bakar yang berbeda yang meliputi warna, bau (aroma), rasa, tekstur, juiciness, dan daya terima (the average of sensory score goat meat satay with different fuel type and grilling time include color, smell, flavor, texture, juiciness and acceptance)

\begin{tabular}{|c|c|c|c|c|c|c|}
\hline \multirow[b]{2}{*}{ Variabel (variable) } & \multicolumn{3}{|c|}{ Arang (charcoal) } & \multicolumn{3}{|c|}{ Gas } \\
\hline & $\begin{array}{c}3 \text { menit } \\
(3 \text { minute })\end{array}$ & $\begin{array}{c}5 \text { menit } \\
(5 \text { minute })\end{array}$ & $\begin{array}{c}7 \text { menit } \\
\text { (7 minute) }\end{array}$ & $\begin{array}{c}3 \text { menit } \\
(3 \text { minute })\end{array}$ & $\begin{array}{c}5 \text { menit } \\
(5 \text { minute })\end{array}$ & $\begin{array}{c}7 \text { menit } \\
\text { (7 minute) }\end{array}$ \\
\hline Warna (color) & $1,40^{\mathrm{a}}$ & $1,87^{b}$ & $2,67^{\mathrm{c}}$ & $1,67^{\mathrm{a}}$ & $2,20^{b}$ & $2,87^{\mathrm{C}}$ \\
\hline $\mathrm{Bau} /$ aroma $(\text { smell })^{\mathrm{ns}}$ & 2,13 & 1,93 & 2,33 & 2,00 & 1,93 & 2,20 \\
\hline Rasa (flavor) & $2,33^{\mathrm{ab}}$ & $2,13^{\mathrm{a}}$ & $2,53^{\mathrm{b}}$ & $2,20^{\mathrm{ab}}$ & $1,67^{\mathrm{a}}$ & $2,40^{\mathrm{b}}$ \\
\hline Tekstur (texture $)^{\mathrm{ns}}$ & 2,60 & 2,53 & 2,80 & 2,20 & 1,93 & 2,80 \\
\hline Juiciness & $2,20^{\mathrm{a}}$ & $2,53^{\mathrm{ab}}$ & $2,93^{\mathrm{b}}$ & $1,80^{\mathrm{a}}$ & $2,33^{\mathrm{ab}}$ & $2,67^{\mathrm{b}}$ \\
\hline Daya terima (acceptance) & $2,33^{\mathrm{a}}$ & $2,33^{\mathrm{ab}}$ & $2,47^{\mathrm{b}}$ & $1,93^{\mathrm{a}}$ & $1,73^{\mathrm{ab}}$ & $2,53^{\mathrm{b}}$ \\
\hline
\end{tabular}

\section{Bau (aroma) sate daging kambing}

Hasil uji Kruskal-Wallis menunjukkan bahwa jenis bahan bakar dan lama pembakaran yang berbeda berpengaruh tidak nyata terhadap aroma (bau) sate daging kambing. Hasil ini karena kambing yang digunakan relatif masih berumur muda sehingga bau khas daging tidak terlalu tajam yang akan mempengaruhi terhadap tingkat kesukaan konsumen. Selain itu, dikarenakan bumbu yang digunakan mempengaruhi aroma sate. Aroma bumbu lebih tajam sehingga dapat menghilangkan bau daging kambing. Hal ini dikarenakan umumnya bumbu bersifat aromatik yang tinggi dan banyak mengandung minyak atsiri esenseial. Bumbu dan turunannya dapat juga berperan sebagai penghambat pertumbuhan bakteri, kapang, fungi, dan mikroorganisme yang bersifat toksik (Souza et al., 2005). Bau goaty berasal dari feromon yang dihasilkan tubuh kambing terutama kambing jantan. Bihaqi dan Jalal (2010) menyatakan bahwa kambing adalah hewan yang bersih dan pejantan memiliki bau khas yang muncul selama musim kawin, sedangkan kambing betina tidak berbau. Ditambahkan oleh Uriarte et al. (2012) bahwa kambing memiliki kelenjar tanduk yang menghasilkan bau khas goaty.

Rerata angka penilaian panelis menunjukkan antara sangat suka dan mendekati agak suka dengan aroma sate daging kambing. Hal ini karena bau goaty tidak tajam sehingga panelis menyukai aroma sate. Penambahan bumbu pada olahan juga mengakibatkan adanya perubahan aroma. Diduga aroma bumbu lebih tajam dibandingkan dengan aroma goaty dari daging. Bumbu yang dihaluskan kemudian direndam beberapa saat diduga dapat mengurangi bau goaty dalam daging.

\section{Rasa sate daging kambing}

Hasil analisis menunjukkan bahwa lama pembakaran berpengaruh nyata terhadap rasa sate daging kambing. Lama pembakaran 3 menit tidak berbeda nyata dengan lama pembakaran 5 dan 7 menit. Lama pembakaran 5 dan 7 menit berbeda nyata $(\mathrm{P}<0,05)$. Hal ini karena terdapat perbedaan tingkat kesukaan antara lama pembakaran 5 dan 7 menit oleh panelis. Sate daging kambing yang dibakar pada waktu terlama yaitu 7 menit memiliki skala kualitas terendah dengan nilai tertinggi untuk 
rasa yang mengartikan agak suka kemungkinan karena rasa daging bakar yang sangat kuat atau terkesan gosong dan pahit. Pemasakan yang terlalu lama pada suhu tinggi akan menimbulkan flavor smoky yang merupakan komponen off flavor. Senyawa yang memberikan aroma smoky atau asap adalah 2,6-Dimetokifenol (Ney, 1992).

Rasa dapat ditimbulkan karena pemberian bumbu. Bumbu yang digunakan mempunyai takaran yang sama, sehingga dimungkinkan memiliki rasa yang sama dan tidak mempengaruhi sate daging kambing.

\section{Tekstur sate daging kambing}

Hasil analisis Kruskal-Wallis menunjukkan bahwa jenis bahan bakar dan lama pembakaran berpengaruh tidak nyata terhadap tekstur dari sate daging kambing. Hal ini diduga dipengaruhi oleh kadar air yang semakin sedikit sehingga tekstur mengkerut dan sedikit kasar. Permukaan daging yang dikeringkan akan mengeras karena daging kehilangan kandungan air selama pemanasan (Soeparno, 2009). Smith (2001) menyatakan bahwa sifat fisik daging, seperti warna, tekstur, kekerasan dan keempukan daging dipengaruhi oleh daya mengikat air, kadar air merupakan kemampuan matriks protein untuk menahan air atau menyerap air yang ditambahkan karena pengaruh luar seperti pemasakan. Kekerasan merupakan faktor penentu dalam pembentukan tekstur suatu produk (Aberle $e t$ al., 2001).

Selain kadar air dalam daging, lemak intramuskular juga mempengaruhi dari tekstur daging. Soeparno (2009) menyatakan bahwa daging yang hampir tidak mempunyai marbling bisa tampak kering dan mempunyai flavor yang kurang baik daripada daging yang cukup mengandung marbling, sedangkan marbling yang terlalu banyak akan membatasi palatabilitas. Marbling tidak banyak terpisah dari otot selama pemasakan karena pengkerutan daging menjadi minimal, sedangkan jus daging dan flavor akan maksimal. Toldra (2010) menyatakan bahwa tekstur suatu produk yang dihasilkan tergantung pada banyaknya protein miofibrillar yang terdegradasi, tingkat pengeringan, tingkat degadrasi jaringan penghubung dalam daging dan kandungan lemak intramuskular dalam daging.

Dari hasil rerata panelis menilai tekstur dari halus sampai agak kasar. Nilai rerata terendah agak kasar pada 7 menit pembakaran terlama kemungkinan dikarenakan sate daging kambing mempunyai tekstur kering bagian luarnya.

\section{Juiciness sate daging kambing}

Juiciness daging adalah kesan juicy atau berair pada daging ketika dikunyah atau digigit di dalam mulut. Beberapa konsumen lebih menyukai daging dengan kesan juiciness tetapi ada sebagian yang lebih menyukai daging dengan juiciness yang rendah dengan alasan daging juiciness di dalam mulut terkesan basah dan berlemak.

Nilai rerata kesan juiciness oleh panelis dari mendekati suka sampai agak suka. Hasil analisis menunjukkan lama pembakaran 3 menit berbeda nyata dengan pembakaran 7 menit, berbeda tidak nyata dengan pembakaran 5 menit. Lama pembakaran 5 menit tidak berbeda nyata dengan lama pembakaran 3 dan 7 menit. Panelis menyukai kesan juiciness yaitu pada pembakaran 3 menit, sedangkan nilai yang menunjukkan agak suka yaitu pada menit ke-7. Hal ini karena pada pembakaran 7 menit kesan juiciness menunjukkan kualitas terendah dengan angka tertinggi, daging bertekstur kering karena kadar air yang rendah. Panelis menyukai pembakaran pada 3 menit diduga karena pada lama pembakaran tersebut kadar air dalam daging masih tinggi.

Jenis bahan bakar tidak mempengaruhi tingkat juiciness, berdasarkan skor skala panelis lebih menyukai pembakaran dengan bahan bakar gas, gas bara api lebih stabil sehingga air yang hilang tidak drastis menurun, kesan juicy atau berair masih sangat terasa. Menurut Beriain et al. (2000) juiciness daging dapat dirasakan dalam dua cara, pertama yaitu sensasi kadar air atau kelembaban saat pertama kali pengunyahan yang mengeluarkan juice, kedua yaitu pengaruh stimulasi lemak pada sekresi saliva. Kesan juiciness dipengaruhi oleh kadar air dan kadar lemak dalam daging. Kandungan air berbanding terbalik dengan kandungan lemak (Uriarte et al., 2012).

\section{Daya terima sate daging kambing}

Hasil analisis menunjukkan lama pembakaran 3 menit berbeda tidak nyata dengan lama pembakaran 5 menit, tetapi berbeda nyata dengan perlakuan lama 7 menit. Lama pembakaran 5 menit berbeda tidak nyata dengan perlakuan lama 3 dan 7 menit. Perlakuan lama pembakaran 3 menit dengan bahan bakar gas menunjukkan nilai yang paling baik dengan indikasi sangat suka. Pembakaran selama 7 menit menggunakan bahan bakar gas mempunyai nilai terendah dengan indikasi suka mendekati agak suka. Berdasarkan nilai rerata penilaian menunjukkan sate daging kambing dapat diterima dengan baik oleh panelis. Hal ini diduga karena secara keseluruhan dari warna, rasa, tekstur maupun juiciness dapat diterima dan disukai oleh panelis.

Daya terima konsumen secara umum selain dari aspek visual dapat juga berdasarkan aspek nutrisi. Resurreccion (2002) menyatakan bahwa karakteristik produk yang paling penting yang 
konsumen lakukan sebagai dasar evaluasi kualitas adalah sifat penampilan yaitu kandungan lemak dan warna. Lemak dianggap sebagai sesuatu sisi yang negatif yang berhubungan dengan kesehatan, sedangkan sisi positif dari lemak seperti mempengaruhi rasa, kelembutan dan keempukan terkadang tidak dianggap sebagai sesuatu yang penting.

Daya terima sate daging kambing oleh panelis diduga lebih berdasarkan dari segi visual atau penampakan dan kesukaan. Lama pembakaran dan bahan bakar yang digunakan selama pembakaran dapat mempertahankan kualitas gizi dan bentuk fisik yang masih dapat diterima sehingga menghasilkan produk yang menarik dan lezat.

\section{Kadar benzo(a)piren sate daging kambing}

Hasil kadar benzo(a)piren sate daging kambing dengan lama pembakaran dan jenis bahan bakar yang berbeda disajikan pada Tabel 4 .

Hasil pengujian kadar benzo(a)piren tidak melebihi batas maksimal yang ditetapkan Standar Nasional Indonesia yaitu 0,2-10 ppb. Kadar benzo(a)piren pada sate yang dibakar dengan arang menunjukkan kadar yang lebih tinggi dibandingkan dengan yang dibakar menggunakan gas. Hal ini diduga disebabkan karena arang merupakan hasil dari pirolisis kayu yang di dalamnya terdapat kandungan $\mathrm{PAH}$ sehingga akan memberikan kontribusi terhadap penambahan jumlah benzo(a)piren. Darmadji (1997) menyatakan bahwa kadar benzo(a)piren sate daging kambing sebesar $1,76 \mathrm{ppb}$ yang dibakar dengan arang, sedangkan yang dibakar dengan kompor gas sebesar $0,78 \mathrm{ppb}$. Terzi et al. (2008) mendeteksi konsentrasi benzo(a)piren pada sampel daging yang dimasak dengan bara api sebesar $24,2 \mu \mathrm{g} / \mathrm{kg}$ dan $5,7 \mu \mathrm{g} / \mathrm{kg}$ daging dimasak dengan gas.

FAO dan WHO menetapkan konsentrasi benzo(a)piren maksimum di dalam makanan adalah $10 \mu \mathrm{g} / \mathrm{kg}$ (WHO, 1987), sedangkan Turki Food Codex menetapkan $1 \mu \mathrm{g} / \mathrm{kg}$ dan $5 \mu \mathrm{g} / \mathrm{kg}$ ditetapkan oleh Komisi Eropa (European Comission, 2005). Indonesia menetapkan cemaran kimia dalam pangan kadar benzo(a)piren dengan kisaran 0,2-10 ppb (Yuniarti, 2010).
Polycyclic aromatic hydrocarbon (PAH) dinilai berbahaya karena bersifat karsinogenik. Polycyclic aromatic hydrocarbon dapat terserap ke dalam tubuh. Akumulasi jumlah PAH dalam tubuh dinilai dapat membahayakan. Terbentuknya benzo(a)piren dipengaruhi oleh jenis bahan bakar, pirolisis lemak dan suhu yang digunakan untuk pembakaran. Terzi et al. (2008) menyatakan bahwa pada dasarnya pembentukan benzo(a)piren sangat ditentukan oleh metode memasak dan sejauh mana daging dimasak. Senyawa PAH cenderung terbentuk atau terdapat pada permukaan daging daripada di bagian dalamnya. Senyawa ini dihasilkan melalui proses pirolisis selama daging dibakar dengan arang dan ketika lemak dari daging menetes ke bara api panas, akan menghasilkan tingkat PAH yang siginifikan selama pemasakan langsung daging dengan arang. Produksi PAH dalam daging yang dimasak langsung di atas arang dipengaruhi oleh konsentrasi lemak dalam daging dan kedekatan makanan dari sumber panas.

Kusnandar (2010) menyatakan bahwa titik leleh adalah suhu dimana lemak/minyak berubah wujud dari padat menjadi cair. Titik leleh minyak/lemak ditentukan oleh ada tidaknya ikatan rangkap asam lemak penyusunnya. Asam lemak jenuh memiliki titik leleh yang lebih tinggi dibandingkan dengan asam lemak tidak jenuh. Titik leleh juga dipengaruhi oleh panjang rantai asam lemak penyusun lemak/minyak, dimana lemak yang tersusun oleh asam lemak rantai pendek akan memiliki titik leleh yang lebih rendah dibandingkan yang disusun oleh asam lemak rantai panjang. Daging kambing mengandung asam lemak jenuh tinggi. Titik leleh asam lemak jenuh akan mempengaruhi ketika terjadi pemanasan, sehingga akan mempengaruhi ketika penetesan ke dalam arang dan mempengaruhi pembentukan benzo(a)piren melalui pirolisis lemak.

Asap merupakan dispersi uap asap dalam udara, yang dihasilkan dari proses distilasi kering atau pirolisis biomassa seperti kayu, kulit kayu, tempurung, sabut, bambu, daun dan lain sebagainya. Proses pirolisis ini akan menghasilkan seperti fenol, tar dan senyawa PAH yang terjadi pada suhu $>500^{\circ} \mathrm{C}$ (Darmadji, 2009).

Tabel 4. Kadar benzo(a)piren sate daging kambing dengan lama pembakaran dan jenis bahan bakar yang berbeda (ppb) (benzo(a)pyren goat meat satay levels with different fuel and grilling time (ppb))

\begin{tabular}{lcccc}
\hline \multirow{2}{*}{ Jenis sate (satay type) } & \multicolumn{3}{c}{ Lama pembakaran (menit) (grilling } & \multirow{2}{*}{ Rerata (average) } \\
\cline { 2 - 4 } & 3 & 5 & 7 & \\
\hline Bakar arang (charcoal grilling) & 2,55 & 4,16 & 5,02 & 4,18 \\
Bakar gas (gas grilling) & 0,68 & 2,71 & 1,65 & 1,65 \\
\hline
\end{tabular}


Hasil penelitian Jaya et al. (1997) menyatakan bahwa kandungan benzo(a)piren tertinggi diperoleh pada asap cair tempurung kelapa, karena kandungan ligninnya paling tinggi. Perbedaan jenis kayu berhubungan dengan perbedaan komposisinya terutama kadar lignin. Sesuai pendapat Maga (1987) yang menyatakan bahwa komposisi kayu mempengaruhi kandungan benzo(a)piren, dimana kayu mengandung lignin yang lebih tinggi karena akan terbakar lebih panas dibandingkan kayu dengan lignin yang lebih sedikit. Dengan demikian semakin banyak lignin yang terdekomposisi, sehingga lebih banyak benzo(a)piren yang terbentuk. Penjual sate menggunakan arang untuk pembakarannya, arang yang digunakan dapat berasal dari berbagai jenis seperti arang kayu, arang tempurung kelapa, dan briket arang. Taufik (2006) menyatakan bahwa dari 30 sampel yang diteliti, 33\% warung sate menggunakan arang kayu, 63,3\% warung sate menggunakan arang batok kelapa, dan 3,3\% warung sate menggunakan kombinasi arang kayu dan batok kelapa.

Jenis bahan bakar gas yang digunakan adalah gas LPG. Widiarto et al. (2011) menyatakan bahwa gas LPG umumnya digunakan untuk keperluan rumah tangga dan digunakan untuk pemanggang (barbecue). Komponen utamanya adalah gas propane $\left(\mathrm{C}_{3} \mathrm{H}_{8}\right)$ dan butane $\left(\mathrm{C}_{4} \mathrm{H}_{10}\right)$ kurang lebih sebanyak $99 \%$ dan selebihnya adalah zat pembau. Pyle et al. (1994) menambahkan barbecue menggunakan gas propane lebih nyaman dan menghasilkan emisi yang lebih sedikit daripada menggunakan arang. Api dari gas propane menghasilkan karbondioksida dan hidrokarbon dengan jumlah yang lebih sedikit daripada arang. Pembakaran menggunakan gas lebih cepat dan lebih aman. Pembakaran menggunakan arang akan menyebabkan cairan menetes ke bara, menguap dan menyebabkan kontaminasi, menggunakan gas dapat langsung dimatikan dan panas berhenti sehingga cepat menyesuaikan dengan suhu lingkungan.

Kadar benzo(a)piren dinilai paling rendah dan lebih aman dikonsumsi dengan pembakaran menggunakan jenis bahan bakar gas dan tidak terlalu lama pembakarannya dengan tetap memperhatikan daging matang sehingga tidak ada cemaran mikroba di dalam daging.

\section{Kesimpulan}

Kesimpulan dari penelitian ini adalah lama pembakaran memberi perubahan warna, rasa, juiciness, daya terima dan kadar benzo(a)piren sate daging kambing. Namun, lama pembakaran tidak mempengaruhi bau dan tekstur sate daging kambing. Jenis bahan bakar tidak mempengaruhi kualitas sensoris sate daging kambing. Kadar benzo(a)piren lebih tinggi dihasilkan pada sate daging kambing yang dibakar dengan arang. Saran yang dapat diberikan adalah perlu dilakukan penelitian pembakaran tidak langsung dengan menggunakan pembungkus atau alas daun pisang atau aluminium foil untuk mengurangi kadar benzo(a)piren.

\section{Daftar Pustaka}

Aberle, E., J. C. Forrest, D. E. Gerrad and E. W. Mills. 2001. Principles of Meat Science. Kendall Publishing Company. Iowa.

Beriain, M. J., A. Purroy, T. Treacher and P. Bas. 2000. Effect of animal and nutritional factors and nutrition on lamb meat quality. In: Sheep and Goat Nutrition: Intake, Digestion, Quality of Products and Rangelands. Ledin I. and Moran d-Feh rP. (eds). Zaragoza: 75-86.

Benford, D., M. Dinovi and R. W. Setzer. 2010. Application of the margin-of-exposure (MoE) approach to substances in food that genotoxic and carcinogenic e.g : benzo(a)pyrene and polycyclic aromatic hydrocarbons. Food Chem. Toxicol. 48: 42-48.

Bihaqi, S. F. and H. Jalal. 2010. Goaty odor and its prevention. Res. J. Agric. Sci. 1: 487-490.

Chen, J. and S. Chen. 2004. Removal of polycyclic aromatic hydrocarbons by low density polyethylene from liquid model and roasted meat. Food Chem. 90: 461-469.

Darmadji, P. 1997. Investigasi senyawa karsinogen benzopyrene dalam sate. Laporan Penelitian. Jurusan Teknologi Hasil Pertanian, Fakultas Pertanian, Universitas Gadjah Mada. Yogyakarta.

Darmadji, P. 2009. Teknologi asap cair dan aplikasinya pada pangan dan hasil pertanian. Pidato Pengukuhan Jabatan Guru Besar dalam Bidang Teknologi Pangan dan Hasil Pertanian. Fakultas Teknologi Pertanian, Universitas Gadjah Mada. Yogyakarta.

Direktorat Jenderal Peternakan. 2011. Populasi Ternak. Badan Pusat Statistik Republik Indonesia. Available at www.bps.go.id Accession date: 19 Juni, 2013.

European Comission. 2005. Directive No. 208/2005, amending Regulation (EC) No. 466/2001 as Regard Polycyclic Aromatic Hydrocarbons. Official Journal of European Union, Brussels, Belgium.

Jaya, I. Ketut, P. Darmadji, dan Suhardi. 1997. Penurunan kandungan benzo(a)pyrene asap cair dengan zeolit dalam upaya meningkatkan keamanan pangan. Prosiding Seminar Teknologi Pangan. Institut Pertanian Bogor. Bogor. 
WHO. 1987. Evaluation of Certain Food Additives and Contaminants. WHO Technical Report Series 31. JECFA.

Kusnandar, F. 2010. Mengenal Sifat Lemak dan Minyak. Departemen Ilmu Teknologi Pangan. Institut Pertanian Bogor. Bogor.

Maga, J. A. 1987. Smoke in Food Processing. CRC Press Inc. Boca Raton. Florida.

Moeljanto, R. 1998. Pengolahan Ikan untuk Indonesia. Nelpan. Jakarta.

Muchtadi, D., N. Palupi, dan M. Astawan. 1993. Metabolisme Zat Gizi Sumber dan Kebutuhan bagi Tubuh Manusia. Pustaka Sinar Harapan. Jakarta.

Ney, K. H. 1992. Cocoa off flavors. In: Off Flavors in Foods and Beverages. Charalambous, G. (ed). Elsevier Science Pub. B. V. Amsterdam.

Pyle, W., J. Dabritz., R. Cortez and J. Healy. 1994. Barbecuing with Hydrogen Gas Diffusion Burners for Hydrogen. FraunhoferGesellschaft Institute for Solar Energy System. Freiberg, Germany.

Resurreccion, A. V. A. 2002. Sensory aspects of consumer choices for meat and meat products. Meat Sci. 66: 11-20.

Smith, D. M. 2001. Fuctional properties of muscle proteins in processed poultry products. In: Poultry Meat Processing. A. R. Sams (ed). CRC Press. Washington.

Soeparno. 2009. Ilmu dan Teknologi Daging. Gadjah Mada Press. Yogyakarta.

Souza, E. L., T. L. Stamford, E. O. Lima, V. N. Trajano and M. B. Filho. 2005. Antimicrobial effectiveness of spices: an approach for use in food conservation system. Braz. Arch. Biol. Technol. 48: 549-558.

Steel, R. G. dan J. H. Torrie. 1993. Prinsip dan Prosedur Statistika. Suatu Pendekatan Biometrik edisi kedua. PT. Gramedia Pustaka Utama. Jakarta.
Taufik, C. 2006. Keamanan mengkonsumsi sate daging kambing ditinjau dari aspek pemanasan dan tingkat cemaran mikroba di Kotamadya Jakarta Timur. Tesis Sekolah Pascasarjana. Institut Pertanian Bogor. Bogor.

Terzi, G., T. H. Celik and C. Nisbet. 2008. Determination of benzo(a)pyrene in Turkish doner kebab sample cooked with charcoal or gas fire. Irish J. Agric. Food Res. 47: 187193.

Tiven, N. C., S. Edi, dan Rusman. 2007. Komposisi kimia, sifat fisik dan sensoris bakso daging kambing dengan bahan pengenyal yang berbeda. Majalah Ilmu dan Teknologi Pertanian 27: 1-6.

Toldra, F. 2010. Innovation for Healthier Processed Meats. International Conference on Food Innovation. Food Innova. Valencia.

Uriarte, A. M. E., C. W. Spaeth and K. K. Bolsen. 2012. Nutritional Factors Affecting Sheep Meat Quality. Animal Sciences and Industry. Kansas State University. Kansas.

Watts, B. M., G. L. Ylimaki, L. E. Jeffrey and L. G. Ekics. 1989. Basic Sensory Methods for Food Evaluation. International Development Research centre, Ottawa. Ontario.

Widiarto, Z. K., H. E. Hadi, dan R. Rakhmawati. 2011. Pendeteksi dan Pengamanan Kebocoran Gas LPG (Propana) Berbasis Mikrokontroller melalui Sms sebagai Media Informasi. Available at www.repo.eepisits.edu/1386/1/Makalah.pdf. Accession date: 18 September, 2013.

Yuniarti, P. 2010. Food Safety: Hot issues. Food Review. Direktorat Standardisasi Produk Pangan, Badan POM RI. Bogor. 